\title{
Preliminary Discussion on the Management of Construction Contracts
}

\author{
Yunhua Liu \\ Beijing Jiaotong University \\ Beijing, China \\ Yhliu1@bjtu.edu.cn
}

\begin{abstract}
A contract for construction project is of great significance to the whole project, it relates to the engineering quality, project duration, project cost and all other content, so do the construction contract management can not only avoid unnecessary disputes in the process of engineering construction, but also can guarantee the legitimate rights and interests of contract parties, more conducive to the smooth completion of the project. At present, the problems existing in the part of construction project contract management: The signing of the contract is not tight, Irregularity in the execution of contract, Failure to conduct contract variation when variation is required, Negligence of management of contract documents. This paper is divided by body put forward the following measures: Establishment of rules and regulations and management procedures, Taking full advantage of contract template, Enhancement of awareness of contract, Establishment of sound contract management system, Strengthening of management of contract claim, Inspecting contract performance on a regular basis, Enhancing management of contract documents .The choice of contract management personnel qualified by weight method, so as to ensure the contract management personnel management level and to ensure that the overall level of project management.
\end{abstract}

Keywords-construction;engineering quality; project duration ;project cost;contract management.

A construction contract specifies the rights and obligations of the employer and the contractor. Once executed, the contract is legally binding, and any modification of the contract is hardly possible. It is a common understanding that a well-managed contract is the precondition of well-managed construction project. It is significant to perform in-depth analysis on the problems existing in the management of contracts and find corresponding countermeasures.

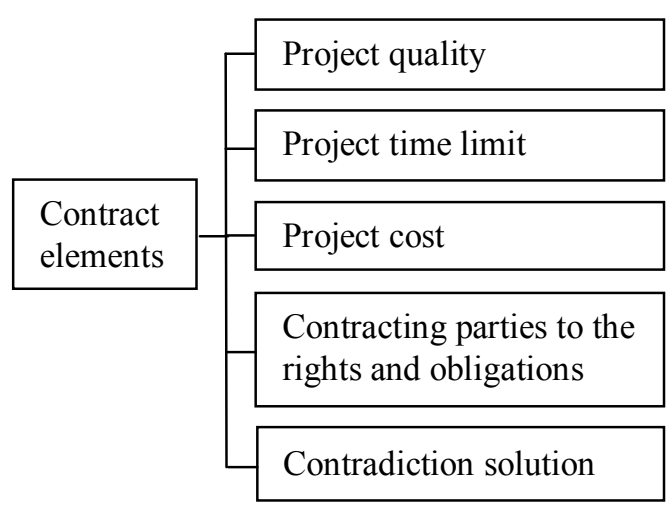

\section{EXISTING PROBLEMS IN THE MANAGEMENT OF CONSTRUCTION CONTRACTS}

From the current status of the construction project contract management, the importance of contract management has attracted more attention, but the intensity is not enough, the technical content of contract management is relatively low. Although many units issued a number of management document to standardize the management of the contract, but the actual implementation is not satisfactory, at present, there are the following problems in the construction project contract management.

\begin{tabular}{|l|l|l|}
\hline The contract & $\begin{array}{l}\text { Without the use of } \\
\text { contract model }\end{array}$ \\
\hline $\begin{array}{l}\text { problems } \\
\text { precision }\end{array}$ & $\begin{array}{l}\text { Affixed the seal is } \\
\text { not the corporate } \\
\text { seal of the } \\
\text { company }\end{array}$ \\
\hline $\begin{array}{l}\text { Irregularity in } \\
\text { the execution } \\
\text { of contract }\end{array}$ & $\begin{array}{l}\text { Failure to conduct } \\
\text { contract variation } \\
\text { when variation is } \\
\text { required }\end{array}$ \\
\hline $\begin{array}{l}\text { Weak contract } \\
\text { management }\end{array}$ & $\begin{array}{l}\text { Failure to send } \\
\text { correspondence } \\
\text { when required }\end{array}$ \\
\hline $\begin{array}{l}\text { Negligence of } \\
\text { management of } \\
\text { contract } \\
\text { documents }\end{array}$ \\
\hline
\end{tabular}

\section{A. Lack of precision}

A contract for construction project generally includes three parts: the agreement, general conditions and particular conditions. Different particular conditions are applied to different construction projects. Currently, the construction project management departments tend to ignore the clarity of sensitive terms in the particular conditions, which could give rise to future disputes and economic losses. Upon the execution of a contract, when the construction project management departments fail to consider the contract as the basis for resolving disputes, such a contract would lack operability and adequacy. 


\section{B. Irregularity in the execution of contract}

1) A contract for a project subject to public bidding is usually entered into by reference to a contract template, while a contract for projects that do not go through the public bidding process is often made based on selfdeveloped, non-standard contract text. For some isolated piecemeal projects, a simple agreement is usually arrived at without specifying the rights and obligations of both parties, out of which unnecessary disputes and trouble for the late stage maintenance could arise.

2) Some contracts are affixed with the seal of internal functional departments, instead of the corporate seal. As the seal of internal functional departments is not legally binding, such contracts are null and void.

3) While the qualifications of a contractor that participates in public bidding are generally proven, a contractor that participates in projects that do not require public bidding would use the qualifications of others.

4) Failure to conduct contract variation when variation is required

Contract variation includes content alteration and the change of contractual subjects. The purpose of contract variation is to ensure better performance of the contract and attainment of certain goals by altering the original contract. Failure to carry out variation when variation is required could cause disputes between the two parties o the contract in the future project management process.

5) Failure to send correspondence when required

Timely delivery of necessary correspondence in the course of contract performance is the need for dynamic management of the contract, a method for contract performance as well as a measure of self protection for enterprises. However, most enterprises have not given enough attention to the timely issuance of correspondence.

6) Negligence of management of contract documents

The contract and related documents formed in connection with contract performance and handling of related issues are valuable treasure of the enterprise as well as the basis for dispute settlement. Proper maintenance of relevant information and establishment of the contract database are critical, as management of the contract documents ensures the successful progress of the project and is an optimal measure to accumulate information and experience in future project management process. Failure of most enterprises to pay attention to contract documents management could cause consequences such as delayed information and incomplete data for daily project management and could result in the lack of basic information needed for improving contract management.

\section{Weak contract management}

Currently, the construction project management departments of employers are mainly responsible for the signing of the contract, which requires experienced legal and professional personnel. However, availability of such personnel is limited in the project management department of most employers. In many cases, the terms and conditions of the construction contracts are proposed by contractors and then are agreed on and signed by employers upon their review. This will leave room for contractors to avail themselves of loopholes. For example, a contractor has replaced the expression "items outside the bill of quantity" in the clause of variation of works with "items outside the price list". The contractor later requested the adjustment of all the items outside its price list based on this provision, causing certain economic losses to the employer.

\section{COUNTERMEASURES TO BE TAKEN IN VIEW OF THE SAID PROBLEMS}

\section{A. Establishment of rules and regulations and} management procedures

The project management department of employers is required to take measures to implement regulated, institutionalized and standardized contract management, and to establish work system and regulations in connection with the contract management. It should clearly define the organization and procedures of contract management, and every work step from contract drafting, negotiation, scrutiny, execution, performance to contract review. The project contract management procedures should be developed to realize the whole process, dynamic contract tracking management, and to strengthen the management on the variation, adjustment and supplementation of contract during contract performance and to ensure the unity and continuity of the performance of the contract.

\section{B. Enhancement of awareness of law}

The contract management personnel of the project management department of the employer are required to receive professional training so as to be well-versed in applicable laws and regulations. Prior to the signing of the contract, the legal counsel should be consulted on the drafting of the terms and conditions of the contract, to avoid risks arising out of unfamiliarity with relevant laws. In addition, the project management department should invite the whole process auditing team to review the contract, to ensure the compliance of the contract with the laws and regulations.

\section{Emphasis on role of contract}

The project management department of an employer should be fully aware that the contract, apart from its connection with the general goal of the project, is an important basis for the settlement of any disputes between the two parties in the future. When a contract is signed, great importance should be attached to the qualifications and capabilities of the contracting party to protect the employer's legitimate rights and interests. A contract will play a greater role in the construction project management when it addresses both the rights and obligations of the parties and is concluded in line with the principle of fairness and impartiality.

\section{Taking full advantage of contract template}

The model text of the construction project contract used in China is relatively accurate in expressions and complete in terms and conditions. The use of model texts can regulate the contract management and reduce discrepancies and errors in the contract, thereby being conducive to the settlement of some disputes during the performance of the contract. 


\section{E. Enhancement of awareness of contract}

1) Particular conditions of the contract for construction project are established targeting a specific project. In the process of contract signing, scrutiny must be performed on the particular conditions with regard to the characteristics of the specific project to ensure legal compliance of the provisions and to protect the rights and interests of the employer. In the case of unbalanced quotation, if unbalanced quotation appears in the tender documents submitted by the contractor, the settlement method, particularly the settlement method for work variation, must be made clear to avoid losses caused by the unbalanced quotation.

2) The employer should increase its awareness of the contract with respect to the project tender process, to provide all the technical data and site environmental conditions required, so that the contractor could participate in the bid competition in a full and fair environment with minimal risk. The employer is recommended to develop the contract documents precisely, define the contract scope reasonably, and carry out ex ante analysis to determine potential uncertainties and risks and to take corresponding protective measures.

\section{F. Establishment of sound contract management system}

Contract management system mainly refers to the organization network of enterprise contract management. The network of organization refers to the contract management mechanism established at all levels of the enterprise (including full-time and part-time function) to extend the contract management to each level of the enterprise. The organization network, as the core of enterprise contract management system, is ensured by means of regular inspection. The contract management organization should adapt to the needs of contract management and the market, and adjustment and improvement are necessary whenever inadaptable areas of the organization are found.

G. Actively participating in the "honoring contracts and being trustworthy" campaign to improve the contract management of enterprise

The "honouring contracts and being trustworthy" campaign has been conducted by relevant administrative authorities in accordance with the principle of honesty and good faith stipulated in the Contract Law, for the purpose of increasing the rate of contract performance and maintaining the market order and economic order. Enterprises should actively participate in the campaign to create an atmosphere of "honouring contracts and being trustworthy".

H. Different measures to improve the quality of contract management personnel

\section{1) Selection of personnel}

Executives of an enterprise may appoint excellent personnel of the enterprise as contract management personnel based on the qualifications required for such personnel, or may select such personnel through public appraisal and competitive recruitment.

The choice of personnel can use the following formula:

$\mathrm{S}_{1}=\mathrm{R} \times 50 \%+\mathrm{E} \times 20 \%+\mathrm{S}_{2} \times 20 \%+\mathrm{W} \times 10 \%$
$\mathrm{S}_{1}$ is the personnel evaluation score;

$\mathrm{R}$ is the Personal responsibility;

$\mathrm{E}$ is the Personal education;

$\mathrm{S}_{2}$ is the personnel subject or field of study;

$\mathrm{W}$ is the personnel Work experience;

$50 \%, 20 \%, 20 \%, 10 \%$ is the weights of four indexes.

2) Arrangement of on-the-job learning

Enterprises should organize on-the-job learning for contract management personnel based on the actual needs of enterprises and the market. The learning can be conducted in a variety of forms so that the contract management personnel can master the theory and exchange their rich work experience and adapt themselves to market development and the needs of the enterprise.

3) Selection of relevant personnel for further study at relevant universities

Each enterprise should keep excellent contract management personnel. One of the ways to improve the qualifications of contract management personnel is to select and send relevant personnel for further study at universities.

\section{4) Establishment of post responsibility system}

The post responsibility system should be applied to contract management personnel to define their responsibilities, rights and interests, and to establish a mechanism of competition, to reward the contract management personnel who have made contributions and eliminate those unqualified personnel.

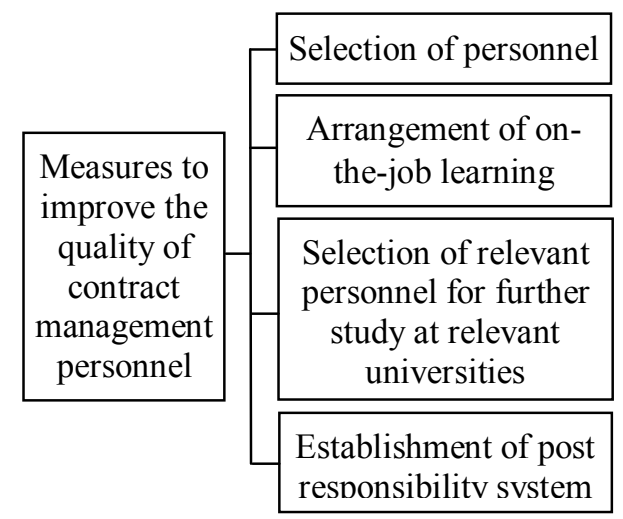

\section{Strengthening of management of contract claim}

Strengthening contract claim management is an important content in the cultivation and development of the sound construction market. Improving claim awareness is an issue that needs to be addressed for contractors and employers. Contract claim management requires enterprises to consider various unfavourable factors when executing a contract, to analyze the probability of contract alteration and claim and to develop effective contract management and claim strategies. During the process of contract performance, relevant information should be collected timely and analysis should be conducted based on the actual situation of the construction site and the laws, regulations and contracts to raise a contract claim at a proper time. 
Contract claim include time claims and cost claims, the cost of the claim is calculated according to the following formula:

$\mathrm{C}=\mathrm{L}+\mathrm{M}_{1}+\mathrm{M}_{2}+\mathrm{M}_{3}+\mathrm{E}+\mathrm{P}+\mathrm{S}+\mathrm{T}$

Where

$\mathrm{C}$ is the cost of the claim;

$\mathrm{L}$ is the cost of labour;

$\mathrm{M}_{1}$ is the cost of materials;

$\mathrm{M}_{2}$ is the cost machinery;

$\mathrm{M}_{3}$ is the Measure Expense;

$\mathrm{E}$ is the enterprise management fees;

$\mathrm{P}$ is the profit;

$\mathrm{S}$ is the statutory fees;

$\mathrm{T}$ is the tax.

\section{J. Inspecting contract performance on a regular basis}

Contract performance should be inspected regularly to keep the contract performance under dynamic management. During the inspection, timely understanding of the performance of the contract should be made. Ongoing contracts, contracts not yet performed and terminated contracts should be reviewed and risk assessment should be conducted and solutions should be proposed.

The following formula can be used to contract risk assessment:

\section{$\mathrm{R}=\mathrm{P} \times \mathrm{S}$}

Where

$\mathrm{R}$ is the risk scores between $0-100$;

$\mathrm{P}$ is the probability of occurrence between 0-100percent;

$\mathrm{S}$ is the severity of risk between $0-100$;

If $\mathrm{R} \leq 20$, the risk can be accepted;

If $20<\mathrm{R} \leq 50$, the risk needs to pay attention to;

If $50<R \leq 80$, the risk is very big, need to adjust the contract;

If $\mathrm{R} \geq 80$, the risk can't be accepted, Need to terminate the contract.

\section{$K$. Enhancing management of contract documents}

In addition to the establishment of a sound contract management mechanism and system, the enterprise should strengthen the management of contract documents. The correspondence from parties, memoranda, and minutes of meetings, fax, telephone records and e-mails generated during the process of contract performance should be collected. For contracts with problems, key evidence from potential disputes should be collected timely. The documentation system, reporting and documentary processing system should be set up for contract management.

\section{CONCLUSION}

Construction contract management is one of the core tasks in the project management of the employer. To strengthen the contract management, importance should be attached to the enhancement of awareness, establishment of regulations and rules, regulation of contract text, development of outstanding contract management personnel, and establishment of dynamic management system, in order to achieve the effective contract management, to avoid or reduce risks, to improve efficiency in the use of construction funds, and to ensure timely completion of construction projects with high quality.

\section{REFERENCES}

[1] Bradshaw, Craig An opportunity to update the management of your building contracts? Building Engineer 2005, 9

[2] Steven Bate, What do you mean, 'be reasonable' Building 2007, 6

[3] FIDIC, Conditions of Subcontract of Subcontract for Work of Civil Engineering Construction. 1994

[4] Geoff Brewer, Direct costs and directly incurred losses, Contract Journal 2005, 4

[5] David Mosey, Early Contractor Involvement in Building Procurement: Contracts, Partnering and Project Management [M], Oxford, Wiley-Blackwell. 2011

[6] The Ministry of Housing and Urban-Rural Development of the People's Republic of China: GB50500-2008 code of bills of quantities and valuation for construction works. China Planning Press, Beijing (2008) "in Chinese"

[7] The Ministry of Housing and Urban-Rural Development of the People's Republic of China: GB50500-2013 code of bills of quantities and valuation for construction works. China Planning Press, Beijing (2013) "in Chinese"

[8] K. C. Iyera, K. N. Jha, Factors Affecting Cost Performance: Evidence From Indian Construction Project, International Journal of Project Management, 23(2005),283-286

[9] Thompson, Innovations Tomanage Disputes, Journal of Management In Engineering, September/ October 2000,51-58

[10] Kathleen M. J. Harmon, Resolution of Construction Disputes: A Review of Current Methodologies, Leadership And Management In Engineering, October2203,187-202 